\title{
Trends in knowledge of HIV status and efficiency of HIV testing services in Sub-Saharan Africa (2000-2020): a modelling study of survey and HIV testing program data
}

\author{
Katia Giguère ${ }^{1}$, Jeffrey W. Eaton ${ }^{2}$, Kimberly Marsh ${ }^{3}$, Leigh F. Johnson ${ }^{4}$, Cheryl C. Johnson ${ }^{5,6}$, Eboi \\ Ehui $^{7}$, Andreas Jahn ${ }^{8,9}$, Ian Wanyeki ${ }^{3}$, Francisco Mbofana ${ }^{10}$, Fidèle Bakiono ${ }^{11}$, Mary Mahy ${ }^{3}$, and \\ Mathieu Maheu-Giroux ${ }^{1}$
}

\footnotetext{
${ }^{1}$ Department of Epidemiology, Biostatistics, and Occupational Health, School of Population and Global Health, McGill University, Montréal, Canada (Katia Giguère, PhD, Mathieu Maheu-Giroux, ScD)

${ }^{2}$ MRC Centre for Global Infectious Disease Analysis, Department of Infectious Disease Epidemiology, Imperial College London, St Mary's Hospital, London, United Kingdom (Jeffrey W. Eaton, PhD)

${ }^{3}$ Strategic Information Department, The Joint United Nations Program on HIV/AIDS (UNAIDS), Geneva, Switzerland (Kimberly Marsh, PhD, Ian Wanyeki, MSc, Mary Mahy, ScD)

${ }^{4}$ Centre for Infectious Disease Epidemiology and Research, University of Cape Town, Cape Town, South Africa (Leigh F. Johnson, $\mathrm{PhD}$ )

5 Global HIV, Hepatitis and Sexually Transmitted Infections Programme, World Health Organization, Geneva, Switzerland (Cheryl C. Johnson, MA)

${ }^{6}$ Department of Clinical Research, London School of Hygiene and Tropical Medicine, London, UK (Cheryl C. Johnson, MA)

${ }^{7}$ Programme national de lutte contre le Sida, Abidjan, Côte d'Ivoire (Eboi Ehui, $\mathrm{PhD}$ )

${ }^{8}$ Department for HIV and AIDS, Ministry of Health and Population, Lilongwe, Malawi (Andreas Jahn, PhD)

${ }^{9}$ Ministry of Health, Lilongwe, Malawi and I-TECH, Department of Global Health, University of Washington, Seattle, USA (Andreas Jahn, PhD)

${ }^{10}$ Conselho Nacional de Combate ao HIV/SIDA, Maputo, Mozambique (Francisco Mbofana, MPH)

${ }^{11}$ Conseil national de lutte contre le Sida et les infections sexuellement transmissibles (CNLS-IST), Ouagadougou, Burkina Faso (Fidèle Bakiono, PhD)
}

\section{Corresponding author:}

Mathieu Maheu-Giroux

Department of Epidemiology, Biostatistics and Occupational Health | McGill University

Purvis Hall

1020 Pine Avenue West

Montreal, QC, Canada H3A 1A2

email: mathieu.maheu-giroux@mcgill.ca

telephone: (+1) 514-398-5110 
medRxiv preprint doi: https://doi.org/10.1101/2020.10.20.20216283; this version posted October 23, 2020. The copyright holder for this preprint (which was not certified by peer review) is the author/funder, who has granted medRxiv a license to display the preprint in perpetuity.

It is made available under a CC-BY 4.0 International license .

\section{Abstract}

2 Background: Knowledge of HIV status (KOS) among people living with HIV (PLHIV) is essential for an effective national HIV response. This study estimates progress and gaps in reaching the UNAIDS 2020 target of 90\% KOS, and the efficiency of HIV testing services (HTS) in sub-Saharan Africa (SSA), where two thirds of all PLHIV live.

Methods: We used data from 183 population-based surveys ( $\mathrm{N}=2.7$ million participants) and national HTS programs ( $N=315$ country-years) from 40 countries as inputs into a mathematical model to examine trends in KOS among PLHIV, median time from HIV infection to diagnosis, HIV testing positivity, and proportion of new diagnoses among all positive tests, adjusting for retesting.

Findings: Across SSA, KOS steadily increased from 6\% (95\% credible interval [95\%CrI]: 5\% to 7\%) in 2000 to $84 \%(95 \% \mathrm{CrI}: 82 \%$ to $86 \%)$ in 2020 . Twelve countries and one region, Southern Africa, reached the $90 \%$ target. In 2020, KOS was lower among men (79\%) than women (87\%) across SSA. PLHIV aged 15-24 years were the least likely to know their status (65\%), but the largest gap in terms of absolute numbers was among men aged 35-49 years, with over 700,000 left undiagnosed. As KOS increased from 2000 to 2020, the median time to diagnosis decreased from 10 to 3 years, HIV testing positivity declined from $9 \%$ to $3 \%$, and the proportion of first-time diagnoses among all positive tests dropped from $89 \%$ to $42 \%$.

Interpretation: On the path towards the next UNAIDS target of $95 \%$ diagnostic coverage by 2030 , and in a context of declining positivity and yield of first-time diagnoses, we need to focus on addressing disparities in KOS. Increasing KOS and treatment coverage among older men could be critical to reduce HIV incidence among women in SSA, and by extension, reducing mother-to-child transmission.

Funding: We acknowledge funding from the Steinberg Fund for Interdisciplinary Global Health Research (McGill University), the Canadian Institutes of Health Research, and the Bill and Melinda Gates Foundation. MMG holds a Canada Research Chair (Tier 2) in Population Health Modeling. KG was supported by a Postdoctoral Fellowship from the Fonds the recherche du Québec - Santé. JWE was supported by UNAIDS, the Bill and Melinda Gates Foundation, and the UK Medical Research Council (MR/R015600/1). 
medRxiv preprint doi: https://doi.org/10.1101/2020.10.20.20216283; this version posted October 23, 2020. The copyright holder for this preprint (which was not certified by peer review) is the author/funder, who has granted medRxiv a license to display the preprint in perpetuity.

It is made available under a CC-BY 4.0 International license.

\section{Research in Context}

\section{Evidence before this study}

One of the major health policy objective of the last decade in the global HIV response has been the adoption of targets to end the AIDS epidemic by 2030. UNAIDS and its partners put forth in 2014 the 90-90-90 objective to increase HIV diagnosis, treatment, and viral load suppression. They called for 90\% of all people living with HIV to have knowledge of their HIV status (KOS) by 2020. There is clear evidence of increases in treatment coverage in sub-Saharan Africa (SSA), but little attention has been devoted to the "first 90" and trends in KOS have not been systematically reviewed and compared.

We searched PubMed from inception to March 2020 without language restriction with the terms "HIV"[Title/Abstract] AND ("test*"[Title/Abstract] OR “diagnos*"[Title/Abstract] OR "knowledge"[Title/Abstract]) AND ("Africa”[MeSH] OR “Africa”[Title/Abstract]), the websites from the Joint United Nations Programme on HIV/AIDS (UNAIDS), and the World Health Organization for HIV testing reports and guidelines. Several studies and reports present KOS estimates for selected countries but none comprehensively examined KOS trends by country, age, and sex, or provided estimates of HIV testing services (HTS) efficiency.

\section{Added value of this study}

Due to incomplete HIV surveillance data, and to non-disclosure of HIV positive status in most population-based surveys, assessment of KOS is challenging and not uniform in SSA. By triangulating household survey data about the proportion of adults ever tested for HIV and HTS program data on the total annual number of HIV tests performed among adults using a mathematical model of testing behaviors, this study is the first to systematically and comprehensively assess how KOS and HTS efficiency evolved in SSA over 20 years, and with stratification by sex, age, and region.

\section{Implications of the available evidence}

The last two decades witnessed remarkable increases in KOS across SSA, but stark sex, age, and regional disparities remain, even in countries that have met the $90 \%$ target overall. Concomitant decreases in median time to diagnosis, HIV testing positivity, and proportion of new diagnoses among all positive tests highlight one of the major challenges faced by testing programs - targeting of HTS to achieve greatest yield of new diagnoses as the undiagnosed population shrinks and diagnosis delays are reduced. With national HIV control programs now contemplating how to reach the next UNAIDS target of $95 \%$ 
medRxiv preprint doi: https://doi.org/10.1101/2020.10.20.20216283; this version posted October 23, 2020. The copyright holder for this preprint (which was not certified by peer review) is the author/funder, who has granted medRxiv a license to display the preprint in perpetuity.

It is made available under a CC-BY 4.0 International license .

diagnostic coverage by 2030 , there is a need to focus on addressing disparities in KOS and to better understand retesting patterns.

\section{Introduction}

Efficient and effective HIV testing services (HTS) are a key component to efforts to end the AIDS epidemic. A positive diagnosis enables people living with HIV (PLHIV) to receive life-saving antiretroviral therapy $(\mathrm{ART})^{1}$ and, for pregnant women living with HIV, risk of mother-to-child HIV transmission can be almost entirely prevented. ${ }^{2}$ At the population level, early diagnosis and treatment could reduce incidence by dramatically lowering viremia such that those with a suppressed viral load are unable to contribute to onward transmission. ${ }^{3}$ HTS also helps identify people who are vulnerable to HIV acquisition and link them to effective HIV prevention services (e.g., voluntary male medical circumcision, pre-exposure prophylaxis). ${ }^{4}$

In sub-Saharan Africa (SSA), where more than two-thirds of PLHIV reside, ${ }^{5}$ HTS were initially provided through voluntary counselling and testing upon request in stand-alone sites. ${ }^{6}$ As HIV treatment became more widely available, provider-initiated HIV testing and counselling emerged, expanding HIV testing services to all patients in health facilities. HTS was also integrated into antenatal care, which greatly increased testing coverage among pregnant and postpartum women. ${ }^{6}$ Such facility-based services were gradually expanded and implementation of community-based services enabled underserved rural and marginalized key populations to be reached by HTS and treatment. ${ }^{7-9}$ The development of new testing technologies and strategies — including point-of-care rapid diagnostic tests, self-testing, partner testing and home-based testing — provided opportunities to accelerate delivery of results and linkage to care. ${ }^{10}$

Recognizing the individual and population benefits of HIV testing and treatment, in 2014, the Joint United Nations Program for HIV/AIDS (UNAIDS) proposed ambitious targets to strengthen the HIV treatment and care cascade such that, by $2020,90 \%$ of PLHIV know their status, $90 \%$ of those diagnosed receive ART, and 90\% of those treated have a suppressed viral load; with each target increasing to $95 \%$ by $2030 .{ }^{11}$ These targets are widely adopted globally, and have motivated shifts in the delivery of HTS, especially in SSA countries with the greatest epidemic burden. Countries monitor and report annually to UNAIDS their progress towards these targets.

However, the proportion of PLHIV who know their status is particularly challenging to monitor in SSA because neither the number of PLHIV, nor the number who are diagnosed, are directly counted. Estimates for PLHIV typically come from mathematical models synthesising HIV serosurvey and antenatal testing data - for example, the UNAIDS-supported Spectrum model. ${ }^{12}$ Aggregate HTS data including the 
medRxiv preprint doi: https://doi.org/10.1101/2020.10.20.20216283; this version posted October 23, 2020. The copyright holder for this preprint (which was not certified by peer review) is the author/funder, who has granted medRxiv a license to display the preprint in perpetuity.

It is made available under a CC-BY 4.0 International license .

number of HIV tests conducted and number of HIV diagnoses, are routinely collected, but reports are often not deduplicated and rates of retesting and re-diagnosis can be high. ${ }^{13,14}$ Household surveys provide cross-sectional data about testing history by HIV status at intervals roughly every five years in most countries, but only a few surveys directly ask respondents if they are aware of their HIV status, a sensitive question that has high potential for non-disclosure. ${ }^{15-17}$ These challenges are compounded by imprecise estimates for the number of new infections by age, sex and geographical area, and by incomplete ascertainment of mortality among the previously diagnosed and undiagnosed population.

Nearing the UNAIDS' interim 2020 target deadline, we sought to evaluate progress towards the 'first 90' HIV diagnosis target in SSA, describe the impact of HTS programs on knowledge of HIV positive status (KOS) and timeliness of HIV diagnosis over the 2000-2020 period, and identify remaining gaps in who is being reached by HTS. We synthesized data from 40 SSA countries about HIV testing history from population-based surveys, HTS program data, and HIV epidemic indicators using a validated mathematical model specifically designed to estimate KOS. ${ }^{13}$ In addition to trends in KOS and diagnosis gaps, we estimated time from HIV infection to diagnosis, probability of getting tested within one year of infection or before reaching a CD4 cell count threshold lower than $350 \mathrm{CD} 4$ cells per $\mu \mathrm{L}$, positivity (proportion of HIV-positive tests among all tests), diagnosis yield (proportion of new diagnoses among all tests), and proportion of new diagnoses among positive tests.

\section{Methods}

\section{Overview}

We previously developed and validated a compartmental deterministic mathematical model (named Shiny90), to synthesize multiple data sources into a coherent framework to longitudinally estimate KOS. This model has been described in detail elsewhere. ${ }^{13}$ Briefly, Shiny 90 models the transition of individuals aged $\geq 15$ years between six stages: 1) HIV-susceptible who have never been tested, 2) HIV-susceptible ever tested, 3) PLHIV who have never been tested, 4) PLHIV unaware who have ever been tested, 5) PLHIV aware (not on ART), and 6) PLHIV on ART. Household surveys and HTS program data are used to estimate the rates of HIV testing among adults not living with HIV and those living with HIV, where HIV testing rates vary with calendar time, sex, age, previous HIV testing status, awareness of status, and, for PLHIV, CD4 cell count category (as a marker of risk of AIDS-related symptoms motivating careseeking and HIV testing). ${ }^{13}$ In this way, the proportion of PLHIV who know their status estimated by 
medRxiv preprint doi: https://doi.org/10.1101/2020.10.20.20216283; this version posted October 23, 2020. The copyright holder for this preprint (which was not certified by peer review) is the author/funder, who has granted medRxiv a license to display the preprint in perpetuity.

It is made available under a CC-BY 4.0 International license .

122 Shiny 90 is bound by ART coverage (minimum) and the proportion of PLHIV who have ever been tested 123 and received the results (maximum).

\section{Data sources and model calibration}

125

126

127

128

129

130

131

132

133

134

135

136

137

138

139

140

141

142

143

144

145

146

147

148

149

150

151

Shiny 90 uses inputs for HIV incidence, mortality, and ART coverage estimated and reported by national governments using the UNAIDS-supported Spectrum modeling software and its Estimation and Projection Package. ${ }^{12}$ The Spectrum model calculates epidemic statistics stratified by age, sex, CD4 cell count category, and ART status. Parameter estimates for HIV disease progression and mortality, as well as demographic rates, are also informed by Spectrum.

Two main data sources are used for estimation of HIV testing rates during model calibration:

1) The proportion of individuals ( $\geq 15$ years old) who self-report having ever been tested for HIV and received the result of the last HIV test from national household surveys conducted between 2000-2019. Estimates were stratified by sex, age (15-24, 25-34, and 35-49 years old), and, if available, HIV sero-status. Sources of national household surveys included Demographic and Health Surveys (DHS; https://dhsprogram.com/Data/), AIDS Indicator Surveys (AIS), Multiple Indicator Cluster Surveys (MICS; www.mics.unicef.org/surveys), Population-based HIV Impact Assessments (PHIA; https://phia-data.icap.columbia.edu/files), and other country-specific surveys (Figure 1). The model was calibrated to data on the proportion ever tested for HIV, but we did not calibrate to self-reported awareness of status data, due to evidence of non-disclosure. ${ }^{15-17}$

2) Data on the total annual number of HIV tests performed among individuals aged $\geq 15$ years and, where available, total number of positive HIV tests (2000-2019) reported by national HIV testing programs. HTS program data are particularly informative about changes in testing levels after the most recent available population-based survey. ${ }^{13}$

For the analyses reported here, we used the Shiny 90 country files submitted to UNAIDS in 2020 (www.unaids.org/en/dataanalysis/datatools/spectrum-epp), including Spectrum, surveys, and program data. Additional programme data sources are listed in appendix (pp 47-50).

Sub-saharan African countries with at least one available survey stratified by HIV sero-status, or countries with surveys not stratified by HIV sero-status but having at least one HTS program data set including total number of positive tests between 2000-2019 were included in analyses. These were the minimal set of survey and HTS program data that were required to calibrate the model for a given country. Countries with a population under 250,000 people, or without available survey data, or with 
medRxiv preprint doi: https://doi.org/10.1101/2020.10.20.20216283; this version posted October 23, 2020. The copyright holder for this preprint (which was not certified by peer review) is the author/funder, who has granted medRxiv a license to display the preprint in perpetuity.

It is made available under a CC-BY 4.0 International license .

152

153

154

155

156

157

158

159

160

161

162

163

164

165

166

167

168

169

170

171

172

173

174

175

176

177

178

179

180

181

182

only survey data not stratified by HIV sero-status and no HTS program data between 2000-2019 were excluded from analyses.

For each country, the model estimates rates of HIV testing by sex, age, HIV status, and testing and treatment history were estimated from the household survey and HTS program data in a Bayesian framework. The mode of the posterior distribution was estimated via optimisation with the BroydenFletcher-Goldfarb-Shanno algorithm ${ }^{18}$ and the posterior density was approximated via Laplace approximation around the posterior mode. ${ }^{13}$ Conceptually, the HTS program data inform rates of HIV testing in the population, while changes in the proportion ever tested by HIV status, sex, and age, alongside estimates of HIV incidence and mortality, inform the proportion of tests conducted among those being HIV tested or diagnosed for the first time versus repeat testing. ${ }^{13}$

\section{Estimating knowledge of HIV status, positivity, and yield}

Using Shiny90 we calculated annual (2000-2020) proportions of PLHIV with KOS (\% of all PLHIV who have ever tested HIV-positive and are thus aware of their HIV status), positivity (\% of all HIV tests that are positive), yield of new diagnoses (\% of new diagnoses out of all HIV tests), and the proportion of new diagnoses out of all positive tests. For post-2019 model predictions, rates of HIV testing were assumed to remain constant at their 2019 values, but with amplified uncertainty guided by variation in historical testing rates. These projections were also guided by historical increases in ART coverage, with coverage achieved in 2020 extrapolated from the 2016-2019 rates of ART initiation. No adjustments were made for the possible impact of coronavirus disease 2019 (COVID-19) disruptions. All indicators can be stratified by sex and age group, and aggregated to regional level by weighting each country's indicator by the number of estimated PLHIV from Spectrum for that calendar year.

\section{Estimating time to diagnosis}

From the annual sex-, age-, HIV testing history-, and CD4 cell count-specific testing rates, we calculated several cross-sectional indicators using period life table methods ${ }^{19}$ that account for the competing risk of AIDS-related death. These include: time from HIV infection to diagnosis, probability of getting tested within one year following infection and before reaching a CD4 count threshold lower than 350 cells per $\mu \mathrm{L}$. These indicators were calculated annually by constructing individual period life tables for each of the 16 baseline strata of sex (men, women), age groups (15-24, 25-34, 35-49, and 50+ years), and HIV testing history (never tested, ever tested). Because the estimates are from period life tables, they reflect the distribution of time to diagnosis if a person who seroconverted in a given year was to experience that year's HIV testing rates by age and CD4 category for their remaining lifetime. Details 
medRxiv preprint doi: https://doi.org/10.1101/2020.10.20.20216283; this version posted October 23, 2020. The copyright holder for this preprint (which was not certified by peer review) is the author/funder, who has granted medRxiv a license to display the preprint in perpetuity.

It is made available under a CC-BY 4.0 International license.

183 of the calculations are presented as supplementary materials (appendix p 1). For each calendar year

184 between 2000 and 2020, we estimated these indicators for the 16 age/sex/testing history strata separately.

185 They were then aggregated to the desired demographic or geographic level (e.g., age, sex, country, region

186 [Western, Central, Eastern, and Southern Africa]) by weighting each stratum by the estimated number of

187 new HIV infections in that stratum for that year (obtained from Spectrum).

188 Uncertainty

189 We obtained uncertainty intervals by drawing 1,000 samples from the posterior distribution of the testing 190 rates estimated by Shiny90. We summarized all indicators using the median, $2.5^{\text {th }}$ and $97.5^{\text {th }}$ percentile

191 of their posterior distribution. We performed analyses using R version 3.5.1 and the Rcpp packages. ${ }^{20}$

192 The code for Shiny90 is available on a public repository (www.github.com/mrc-ide/first90release). We

193 followed the Guidelines for Accurate and Transparent Health Estimates Reporting (GATHER, appendix $194 \mathrm{p} \mathrm{51).21}$

\section{Ethical approval}

196 All analyses were performed on anonymized and deidentified data. All DHS/AIS survey protocols have 197 been approved by the Internal Review Board of ICF International in Calverton (USA) and by the relevant 198 country authorities for other surveys (MICS and PHIA). Further information on the ethics approval can 199 be found in the individual country reports. Ethics approval for secondary data analyses was obtained 200 from McGill University's Faculty of Medicine Institutional Review Board (A10-E72-17B).

\section{Role of the Funding Source}

202 The funders of the study played no role in study design, data collection, data analysis, data interpretation, 203 or writing of the report. The corresponding author had full access to all the data in the study and had final 204 responsibility for the decision to submit for publication.

\section{Results}

206 A total of 40 countries, 183 population-based surveys ( $>2.7$ millions surveyed individuals), and 315 207 country-years of HTS program data reports informed our model (Figure 1). Four SSA countries (Cabo 208 Verde, Central African Republic, Guinea-Bissau, Mauritius) were excluded from the analyses due to 209 insufficient data inputs for model calibration, and one (Sao Tome and Principe), because of high 
medRxiv preprint doi: https://doi.org/10.1101/2020.10.20.20216283; this version posted October 23, 2020. The copyright holder for this preprint (which was not certified by peer review) is the author/funder, who has granted medRxiv a license to display the preprint in perpetuity.

It is made available under a CC-BY 4.0 International license .

210 uncertainty in epidemic statistics for small population sizes $(<250,000$ people). Results of the Shiny 90 211 model calibration are presented in Text S2 (appendix pp 2-42).

212 Across SSA, the proportion of adults 15 years and older (both those living and not living with HIV) 213 estimated to have been tested increased by 48 percentage points from 2000 to 2020 (Table 1). Testing 214 coverage was highest in Southern Africa with 85\% (95\%CrI: 83 to 88\%) of adults projected to have ever 215 been tested in the region in 2020.

216 The proportion of adult PLHIV with KOS increased steadily from 5.7\% (95\%CrI: 4.6 to $7.0 \%$ ) in 2000 217 to $84 \%$ (95\% CrI: 82 to $86 \%$ ) in 2020 in SSA (Table 1). While KOS increased dramatically in all four 218 SSA regions, KOS was consistently lower in Western and Central Africa as compared to Eastern and 219 Southern Africa (Figure 2A; Figure S1: appendix p 43). Within the regions, national estimates were also 220 highly heterogeneous, especially in Eastern Africa with a 77 percentage point difference between the 221 countries with the lowest and highest KOS estimates. Overall, we projected that 12 countries (Figure 3) 223 and one region, Southern Africa, will have reached at least 90\% KOS in 2020. Countries with higher KOS tended to be those in which the annual number of tests relative to the total population aged $\geq 15$ years was highest (Figure S2: appendix p 44).

Our results also suggest disparities in KOS by sex and age. Across SSA in 2020, men had lower KOS 226 (79\%, 95\%CrI: 76 to $81 \%$ ) than women (87\%, 95\%CrI: 85 to $89 \%)$, and 15-24 year-olds were the least likely to know their status (65\%,95\%CrI: 62 to 69\%; Figure 2B-C, Table S4: appendix p 53). Such disparities were also observed among the 12 countries projected to achieve at least $90 \%$ of KOS overall in 2020. Of these countries, only six are projected to achieve $90 \%$ of KOS among men, and none are projected to do so among the 15-24 year-olds.

While the proportion of PLHIV aware of their status was lower among younger adults, the absolute number of PLHIV was also lower. Consequently, in absolute numbers, the largest group of undiagnosed PLHIV in SSA were men aged 35-49 years, with >700,000 left undiagnosed and 305,000 diagnoses needed to reach 90\% awareness of status (Figure 4, Table S3: appendix p 52).

235 The median time from HIV infection to diagnosis (or death) decreased by 7 years from 2000 to 2020 for all of SSA (Table 1; Figure 5A). That is, if projected HIV testing rates in 2020 persisted into the future, $50 \%$ of people infected in 2020 would be diagnosed (or, with small probability, suffer AIDS-related mortality) within 2.6 years of seroconverting. National trends are presented in Figure S3 (appendix p 45). 
medRxiv preprint doi: https://doi.org/10.1101/2020.10.20.20216283; this version posted October 23, 2020. The copyright holder for this preprint (which was not certified by peer review) is the author/funder, who has granted medRxiv a license to display the preprint in perpetuity.

It is made available under a CC-BY 4.0 International license .

$241 \mu \mathrm{L}$ increased respectively by 31 and 52 percentage points from 2000 to 2020 in SSA (Table 1; Figure 242 5B-C).

243 The proportion of all HIV tests that are positive (positivity) decreased by 6 percentage points from 2000 244 to 2020 (Table 1; Figure S4: appendix p 46), and the proportion of new diagnoses among all tests 245 (diagnosis yield) decreased by 7 percentage points. Concommitantly, the proportion of new diagnoses 246 among positive tests decreased by 47 percentage points over the study period (Table 1). That is, we 247 project that 58\% of PLHIV undergoing testing in 2020 will have been previously diagnosed with HIV. 248 For each of the previous outcomes, five-yearly estimates are presented by sex and age stratification and 249 by region in Tables S4 to S8 (appendix pp 53-57).

\section{Discussion}

251 Across SSA, impressive gains were achieved in KOS with 84\% (95\%CrI: 82 to 86\%) of PLHIV being 252 aware of their HIV positive status, and 12 countries and the region of Southern Africa that are projected to reach the $90 \%$ KOS target in 2020 . Concomitant with these improvements, we estimated that median time from HIV acquisition to diagnosis would be reduced to 2.6 years (95\% CrI: 1.8 to 3.5) over that period.

Despite this progress, our results highlight substantial regional, national, sex, and age disparities in KOS in SSA. KOS was consistently lower in Western and Central Africa than Eastern and Southern Africa. In those regions, HIV prevalence is lower but key populations - including sex workers, men who have sex with men, and people who inject drugs — account for a higher HIV burden. For example, they generally represent a small fraction of the population but accounted for $42 \%$ of all new HIV infections in 2019 in the region of Western and Central Africa. ${ }^{5}$ Stigma and discrimination towards key populations are common in many health facilities, which may lead to delayed HIV testing, concealment of HIV positive status, and/or poor uptake of HIV services. ${ }^{22}$ A recent systematic review and meta-analysis has shown that, among men who have sex with men in Africa, lower testing and KOS were associated with more hostile legislation, and that KOS remained low in the region. ${ }^{23}$ To improve coverage of HIV health services in Western and Central Africa, antidiscrimination and protective laws to eliminate stigma and discrimination among key populations should be implemented and enforced, health workers trained and sensitized, and key population-friendly services provided. ${ }^{22}$ Eastern Africa, despite having high KOS across the region, includes the two countries with the lowest KOS — South Sudan and Madagascar. While new HIV infections declined overall in Eastern African countries between 2010 and 2019, new infections 
medRxiv preprint doi: https://doi.org/10.1101/2020.10.20.20216283; this version posted October 23, 2020. The copyright holder for this preprint (which was not certified by peer review) is the author/funder, who has granted medRxiv a license to display the preprint in perpetuity.

It is made available under a CC-BY 4.0 International license.

272

underscores that reducing new HIV infections, 'turning off the tap' of undiagnosed PLHIV, is key to reaching KOS targets.

In all four SSA regions, and consistent with previous studies, men are less likely to know their HIV status compared to women. ${ }^{24-28}$ Overall, the diagnosis gap is such that there is a $8 \%$ point difference between men and women in 2020. Large differences in KOS are also observed between age groups, with the lowest proportion diagnosed being among PLHIV aged 15-24 years. Importantly, all countries have yet to reach $90 \% \mathrm{KOS}$ in this younger group. This gap between age groups is the natural consequence of HIV transmission dynamics. HIV incidence is highest and average time since infection is short - and thus cumulative exposure to testing is lower — in this age group compared to older ones. ${ }^{12}$ To achieve 90\% KOS among 15-24 years-old would require a simultaneous increase in testing with greater investment in HIV prevention to increase coverage of high impact prevention interventions.

While we found that KOS was proportionally the lowest among men aged 15-24 years old, the largest group of undiagnosed PLHIV was men aged 35-49 years, with $>700,000$ projected to be undiagnosed in 2020. Lower uptake of HIV testing among men may be explained by fewer opportunities for testing as well as other social and system-wide barriers such as harmful gender norms ${ }^{7,29}$ and inaccessible or unfriendly services. ${ }^{30}$ Engaging men in HIV prevention efforts is critically important, not only for their own needs, but also for their sexual partners. An increase in KOS and of treatment coverage among older men could be critical to reduce HIV acquisition rates among women, and by extension, reducing motherto-child transmission. Among different testing approaches, community-based testing, door-to-door HTS, home-based couples testing, workplace programs, mobile testing services, social network interventions, incentives to test, self-testing, and partner notification have shown success in increasing diagnostic coverage among men. ${ }^{31}$ As part of these efforts, facilitating linkage and retaining men with HIV care remains a key challenge for further progress towards HIV testing and treatment targets.

Despite improvements, especially in Southern Africa where the median time to diagnosis (or AIDSdeath) was estimated at 1.5 years (95\%CrI: 0.9 to 2.3 ) in 2020, we projected that across SSA and at current testing levels, 50\% of PLHIV will not be diagnosed within 3 years following their infection, and $29 \%$ will not get tested before reaching a CD4 count threshold lower than 350 cells per $\mu \mathrm{L}$ in 2020 . These diagnostic delays impede rapid ART initiation at high CD4 counts which, in its absence, contribute to increased HIV morbidity and onward HIV transmission. ${ }^{1,32-34}$ Reducing diagnostic delays on their own will likely not be enough to improve individual and population health outcomes. Earlier diagnosis should 
medRxiv preprint doi: https://doi.org/10.1101/2020.10.20.20216283; this version posted October 23, 2020. The copyright holder for this preprint (which was not certified by peer review) is the author/funder, who has granted medRxiv a license to display the preprint in perpetuity.

It is made available under a CC-BY 4.0 International license .

302 be accompanied by rapid ART linkage and long-term adherence to ART - these are crucial to 303 minimizing morbidity and reducing HIV incidence. ${ }^{32,33,35}$

304 As the undiagnosed population shrinks and diagnosis delays are reduced, targeting of HTS to achieve 305 greatest yield of new diagnoses is one of the major challenges faced by testing programs. ${ }^{36}$ Although we 306 noted an ecological correlation between a country's testing volume with respect to its population of 307 reproductive age and KOS, we also estimated a decline in positivity and in the yield of new diagnoses. 308 Such declining yields are an inevitable consequence of reaching saturation in testing programs — as long 309 as testing rates are lower in previously-diagnosed individuals than in undiagnosed, we can expect yields 310 to decline as KOS increases. Our analyses also highlight substantial retesting of PLHIV already aware 311 of their status. We projected that $58 \%$ of positive tests will be performed on previously diagnosed PLHIV 312 in SSA in 2020. In previous studies conducted in SSA between 2004 and 2018, retesting among PLHIV 313 with known HIV status was also common, ranging from $13 \%$ to $68 \% .^{14,37-41}$ Retesting can be motivated 314 by multiple factors, one of them being the ability to confirm the accuracy of the initial test result. ${ }^{41-43}$ 315 Another important driver of retesting may be avoiding disclosing prior knowledge of HIV positive status due to societal stigma or denial. A recent study conducted among persons undergoing HIV testing at a 317 health facility in South Africa found that 50\% of patients testing HIV-positive had previously been in 318 HIV care (and hence previously diagnosed). Among these, half did not disclose prior knowledge of HIV 319 status to their health care provider. ${ }^{14}$ Further research is needed to assess the potential benefits of retesting 320 for reengaging PLHIV in care.

321 This analysis has some limitations. First, Shiny90 does not provide estimates of diagnosis coverage 322 among < 15 years-old, nor can it disaggregate metrics by key population groups. Second, we could have 323 overestimated KOS in some low HIV prevalence countries where key populations are disproportionately 324 affected by HIV if these groups are underrepresented in population-based surveys. Third, uncertainty in 325 the PLHIV denominator, HIV incidence estimates, and ART coverage are not accounted for. This does 326 not affect the validity of point estimates, but their precision could be overestimated. Fourth, we assumed 327 that HIV testing does not result in false negative or false positive results. The assumption of no false 328 negative HIV test result may have slightly over-estimated KOS and probability of getting tested within 3291 year or before reaching a CD4 count threshold lower than 350 cells per $\mu \mathrm{L}$, and under-estimated median 330 time to diagnosis or (AIDS-related death). The number of HIV diagnoses reported in HTS programme 331 data could be inflated if WHO-recommended retesting to verify HIV diagnosis before ART initiation 332 was incorrectly counted as separate HIV diagnoses, which our model would not be able to identify from 333 routinely reported data. Fifth, we also assumed that self-reporting of HIV testing histories was accurate 
medRxiv preprint doi: https://doi.org/10.1101/2020.10.20.20216283; this version posted October 23, 2020. The copyright holder for this preprint (which was not certified by peer review) is the author/funder, who has granted medRxiv a license to display the preprint in perpetuity.

It is made available under a CC-BY 4.0 International license .

334 but social desirability and recall biases could result in underestimation of the proportion ever tested and, 335 ultimately, of KOS. ${ }^{44}$ However, validation of self-reported HIV testing histories by mean of antiretroviral 336 biomarkers data from PHIA surveys from eSwatini, Malawi, Tanzania, and Zambia using Bayesian latent 337 class model suggest that, self-reported HIV testing history being highly sensitive, underestimation of the 338 proportion ever tested and of KOS should be low (Xia et al. preprint). ${ }^{45}$ Sixth, earlier estimates of 339 diagnosis delays are informed by relatively few population-based survey estimates and HTS program 340 data. Given the cross-sectional nature of these metrics, they could be more sensitive to the elicited 341 model's prior distributions in early years. Finally, the impact of measures taken to prevent the spread of 342 COVID-19 in some countries could have affected both HIV incidence and HTS. ${ }^{46}$ Such unacounted 343 factors could potentially lead to slightly lower KOS estimates than those projected in 2020, although a 344 notable decrease would be unlikely since already diagnosed PLHIV would remain so.

345 Although previous studies examined HIV testing uptake or self-reported KOS at community or country 346 level, the present analysis is believed to be the first to systematically and comprehensively assess how 347 HTS efficiency evolved in SSA over 20 years. By using a unified framework to compare HTS metrics, 348 consistency and comparability of results between the different outcomes, countries, and regions is 349 improved. A second strength is the large number of surveys and program data used for triangulation, 350 improving the precision and robustness of our results. Third, in assessing time to diagnosis (or AIDS351 related death) and other related metrics, we provide valuable information to help programs optimize HTS 352 efficiency. ${ }^{47}$ With clear individual and population-health benefits of early treatment initiation, reducing 353 diagnostic delays and improving linkage to care will contribute towards the ultimate goal to end AIDS 354 epidemics by 2030.

\section{Conclusion}

356 In 2014, the world adopted the goal of achieving 90\% HIV diagnosis by 2020. Sub-Saharan Africa, the 357 most affected region, is close to reaching this target and we project that 12 countries and one region, 358 Southern Africa, will have reached that goal among adults in 2020. However, reaching 90\% diagnosis 359 coverage remains challenging and our results shed light on stark sex and age gaps in KOS. None of the 36012 countries projected to reach the $90 \%$ target overall are projected to do so in all age and sex groups.

361 National HIV control programs are now contemplating how to reach the next UNAIDS target of 95\% 362 diagnostic coverage by 2030 in a context of declining positivity, declining yields of "true" new diagnoses, 
medRxiv preprint doi: https://doi.org/10.1101/2020.10.20.20216283; this version posted October 23, 2020. The copyright holder for this preprint (which was not certified by peer review) is the author/funder, who has granted medRxiv a license to display the preprint in perpetuity.

It is made available under a CC-BY 4.0 International license .

363 and COVID-19 disruption. Reaching this objective will require a better understanding of retesting

364 patterns and a focus on addressing disparities among older men and young people in KOS.

\section{Contributors}

366 JWE, KG, KM, LFJ, and MMG conceived the study. AJ, JWE, KM, LFJ, and MMG developed the

367 mathematical model. KG performed the analyses. AJ, CCJ, EE, FB, FM, IW, KM, and MM contributed

368 data and helped with result interpretation. KG and MMG wrote the initial draft. AJ, CCJ, EE, FB, FM,

369 IW, KM, LFJ, MM, and IW provided expert input to inform background, context, and local

370 epidemiology. All authors contributed to and approved the final manuscript.

\section{Declaration of interests}

372 We acknowledge funding from the Steinberg Fund for Interdisciplinary Global Health Research (McGill

373 University), the Canadian Institutes of Health Research, and the Bill and Melinda Gates Foundation.

374 MMG holds a Canada Research Chair (Tier 2) in Population Health Modeling and reports other from

375 UNAIDS, other from WHO, grants from Gilead Sciences Inc., outside the submitted work; KG reports

376 a Postdoctoral Fellowship from Fonds de recherche du Québec - Santé, during the conduct of the study;

377 personal fees from UNAIDS, outside the submitted work; JWE reports grands from Bill and Melinda

378 Gates Foundation, grants from UNAIDS, grants from UK Medical Research Council, during the conduct

379 of the study; grants from NIH, grants from UNAIDS, grants from WHO, personal fees from WHO, grants

380 from USAID, outside the submitted work; All other authors has nothing to disclose. The contents in this

381 article are those of the authors and do not necessarily reflect the view of the World Health Organization. 
medRxiv preprint doi: https://doi.org/10.1101/2020.10.20.20216283; this version posted October 23, 2020. The copyright holder for this preprint (which was not certified by peer review) is the author/funder, who has granted medRxiv a license to display the preprint in perpetuity.

It is made available under a CC-BY 4.0 International license .

\section{References}

1. Grinsztejn B, Hosseinipour MC, Ribaudo HJ, et al. Effects of early versus delayed initiation of antiretroviral treatment on clinical outcomes of HIV-1 infection: results from the phase 3 HPTN 052 randomised controlled trial. Lancet Infect Dis 2014; 14: 281-90.

2. Tippett Barr BA, van Lettow M, van Oosterhout JJ, et al. National estimates and risk factors associated with early mother-to-child transmission of HIV after implementation of option B+: a crosssectional analysis. The Lancet HIV 2018; 5: e688-e95.

3. Cohen MS, Chen YQ, McCauley M, et al. Antiretroviral therapy for the prevention of HIV-1 transmission. N Engl J Med 2016; 375: 830-9.

4. World Health Organization. Consolited guidelines on HIV testing services. Geneva, Switzerland; 2015. Access Date:

5. UNAIDS. UNAIDS data 2020. Geneva, Switzerland; 2020. Available from: https://www.unaids.org/en/resources/documents/2020/unaids-data. Access Date: September 10, 2020 6. STAR Initiative, Unitaid, World Health Organization. Knowing your status - then and now: Realizing the potential of HIV self-testing. 2018. Available from: https://unitaid.org/assets/STARInitiative-Report-Knowing-your-status $\%$ E2\%80\%93then-and-now.pdf. Access Date: September 10, 2020

7. UNAIDS. Ending AIDS: Progress towards the 90-90-90 targets. Geneva, Switzerland; 2017. Available from:

https://www.unaids.org/en/resources/documents/2017/20170720_Global_AIDS_update_2017. Access Date: January 16, 2020

8. Suthar AB, Ford N, Bachanas PJ, et al. Towards universal voluntary HIV testing and counselling: a systematic review and meta-analysis of community-based approaches. PLoS Med 2013; 10: e1001496.

9. Rodriguez-Garcia R, Bonnel R, Wilson D, N'Jie ND. Investing in communities achieves results: Findings from an evaluation of community responses to HIV and AIDS. Washington, D.C.: The World Bank; 2013.

10. Plate DK, Rapid HIV Test Evaluation Working Group. Evaluation and implementation of rapid HIV tests: the experience in 11 African countries. AIDS Res Hum Retroviruses 2007; 23: 1491-8.

11. UNAIDS. Fast track: ending the AIDS epidemic by 2030. Geneva, Switzerland; 2014.

Available from: https://www.unaids.org/en/resources/documents/2014/fast_track. Access Date: January 16,2020

12. Stover J, Glaubius R, Mofenson L, et al. Updates to the Spectrum/AIM model for estimating key HIV indicators at national and subnational levels. AIDS 2019; 33 Suppl 3: S227-S34.

13. Maheu-Giroux M, Marsh K, Doyle C, et al. National HIV testing and diagnosis coverage in sub-Saharan Africa: a new modeling tool for estimating the "first 90" from program and survey data. AIDS 2019; 33: S255-S69.

14. Jacob N, Rice B, Kalk E, et al. Utility of digitising point of care HIV test results to accurately measure, and improve performance towards, the UNAIDS 90-90-90 targets. PLoS One 2020; 15: e0235471.

15. Fishel JD, Barrère B, Kishor S. Validity of data on self-reported HIV status and implications for measurement of ARV coverage in Malawi. Calverton, MD: ICF International; 2012. Access Date:

16. Kim AA, Mukui I, Young PW, et al. Undisclosed HIV infection and antiretroviral therapy use in the Kenya AIDS indicator survey 2012: relevance to national targets for HIV diagnosis and treatment. AIDS 2016; 30: 2685-95.

17. Mooney AC, Campbell CK, Ratlhagana MJ, et al. Beyond social desirability bias: Investigating inconsistencies in self-reported HIV testing and treatment behaviors among HIV-positive adults in North West Province, South Africa. AIDS Behav 2018; 22: 2368-79. 
medRxiv preprint doi: https://doi.org/10.1101/2020.10.20.20216283; this version posted October 23, 2020. The copyright holder for this preprint (which was not certified by peer review) is the author/funder, who has granted medRxiv a license to display the preprint in perpetuity.

It is made available under a CC-BY 4.0 International license.

18. Nash J. Compact Numerical Methods for Computers - Linear algebra and function minimisation. . 2nd ed. Bristol, England: Adam Hilger; 1990.

19. Preston SH, Heuveline P, Guillot M. Demography: measuring and modeling population processes: Malden, MA: Balckwell Publishers; 2001.

20. Eddelbuettel D, Balamuta JJ. ExtendingRwith C++: A Brief Introduction to Rcpp. The American Statistician 2017; 72: 28-36.

21. Stevens GA, Alkema L, Black RE, et al. Guidelines for Accurate and Transparent Health Estimates Reporting: the GATHER statement. The Lancet 2016; 388: e19-e23.

22. World Health Organization. Consolidated guidelines on HIV prevention, diagnosis, treatment and care for key populations. Geneva, Switzerland; 2014. Access Date:

23. Stannah J, Dale E, Elmes J, et al. HIV testing and engagement with the HIV treatment cascade among men who have sex with men in Africa: a systematic review and meta-analysis. The Lancet HIV 2019; 6: e769-e87.

24. Floyd S, Ayles H, Schaap A, et al. Towards 90-90: Findings after two years of the HPTN 071 (PopART) cluster-randomized trial of a universal testing-and-treatment intervention in Zambia. PLoS One 2018; 13: e0197904.

25. Staveteig S, Croft TN, Kampa KT, Head SK. Reaching the 'first 90': Gaps in coverage of HIV testing among people living with HIV in 16 African countries. PLoS One 2017; 12: e0186316.

26. Huerga H, Van Cutsem G, Ben Farhat J, et al. Progress towards the UNAIDS 90-90-90 goals by age and gender in a rural area of KwaZulu-Natal, South Africa: a household-based community crosssectional survey. BMC Public Health 2018; 18: 303.

27. Gaolathe T, Wirth KE, Holme MP, et al. Botswana's progress toward achieving the 2020 UNAIDS 90-90-90 antiretroviral therapy and virological suppression goals: a population-based survey. The Lancet HIV 2016; 3: e221-e30.

28. Marsh K, Eaton JW, Mahy M, et al. Global, regional and country-level 90-90-90 estimates for 2018: assessing progress towards the 2020 target. AIDS 2019; 33 Suppl 3: S213-S26.

29. World Health Organization. Global update on the health sector response to HIV, 2014. Geneva, Switzerland; 2014. Available from:

https://apps.who.int/iris/bitstream/handle/10665/128494/9789241507585_eng.pdf. Access Date: January 16,2020

30. Hawkes S, Buse K. Gender and global health: evidence, policy, and inconvenient truths. Lancet 2013; 381: 1783-7.

31. Quinn C, Kadengye DT, Johnson CC, Baggaley R, Dalal S. Who are the missing men? Characterising men who never tested for HIV from population-based surveys in six sub-Saharan African countries. J Int AIDS Soc 2019; 22: e25398.

32. Cohen MS, Chen YQ, McCauley M, et al. Prevention of HIV-1 infection with early antiretroviral therapy. $N$ Engl J Med 2011; 365: 493-505.

33. Insight Start Study Group. Initiation of antiretroviral therapy in early asymptomatic HIV infection. N Engl J Med 2015; 373: 795-807.

34. TEMPRANO ANRS 12136 Study Group. A trial of early antiretrovirals and isoniazid preventive therapy in Africa. N Engl J Med 2015; 373: 808-22.

35. Eaton JW, Johnson LF, Salomon JA, et al. HIV treatment as prevention: systematic comparison of mathematical models of the potential impact of antiretroviral therapy on HIV incidence in South Africa. PLoS Med 2012; 9: e1001245.

36. World Health Organization. Global Health Sector Strategy on HIV, 2016-2021: Towards Ending AIDS. Geneva, Switzerland: World Health Organization; 2016. Access Date:

37. Angotti N, Bula A, Gaydosh L, Kimchi EZ, Thornton RL, Yeatman SE. Increasing the acceptability of HIV counseling and testing with three C's: convenience, confidentiality and credibility. Soc Sci Med 2009; 68: 2263-70. 
medRxiv preprint doi: https://doi.org/10.1101/2020.10.20.20216283; this version posted October 23, 2020. The copyright holder for this preprint (which was not certified by peer review) is the author/funder, who has granted medRxiv a license to display the preprint in perpetuity.

It is made available under a CC-BY 4.0 International license .

38. Franse CB, Kayigamba FR, Bakker MI, et al. Linkage to HIV care before and after the introduction of provider-initiated testing and counselling in six Rwandan health facilities. AIDS Care 2017; 29: 326-34.

39. Fuente-Soro L, Lopez-Varela E, Augusto O, et al. Monitoring progress towards the first UNAIDS target: understanding the impact of people living with HIV who re-test during HIV-testing campaigns in rural Mozambique. J Int AIDS Soc 2018; 21: e25095.

40. Moore HA, Metcalf CA, Cassidy T, et al. Investigating the addition of oral HIV self-tests among populations with high testing coverage - Do they add value? Lessons from a study in Khayelitsha, South Africa. PLoS One 2019; 14: e0215454.

41. Kulkarni S, Tymejczyk O, Gadisa T, et al. "Testing, Testing": Multiple HIV-Positive Tests among Patients Initiating Antiretroviral Therapy in Ethiopia. J Int Assoc Provid AIDS Care 2017; 16: 546-54.

42. Wringe A, Moshabela M, Nyamukapa C, et al. HIV testing experiences and their implications for patient engagement with HIV care and treatment on the eve of 'test and treat': findings from a multicountry qualitative study. Sex Transm Infect 2017; 93.

43. Horter S, Thabede Z, Dlamini V, et al. "Life is so easy on ART, once you accept it": Acceptance, denial and linkage to HIV care in Shiselweni, Swaziland. Soc Sci Med 2017; 176: 52-9.

44. Rentsch CT, Reniers G, Machemba R, et al. Non-disclosure of HIV testing history in population-based surveys: implications for estimating a UNAIDS 90-90-90 target. Global Health Action 2018; 11.

45. Xia Y, Milwid RM, Godin A, et al. Accuracy of self-reported HIV testing history and awareness of HIV-positive status among people living with HIV in four Sub-Saharan African countries. [Preprint] 2020. Available from: https://www.medrxiv.org/content/10.1101/2020.09.16.20196105v1. Access Date: September 21, 2020

46. Jiang H, Zhou Y, Tang W. Maintaining HIV care during the COVID-19 pandemic. The Lancet HIV 2020; 7: e308-e9.

47. Nash D, Robertson M. How to evolve the response to the global HIV epidemic with new metrics and targets based on pre-treatment CD4 counts. Curr HIV/AIDS Rep 2019; 16: 304-13. 


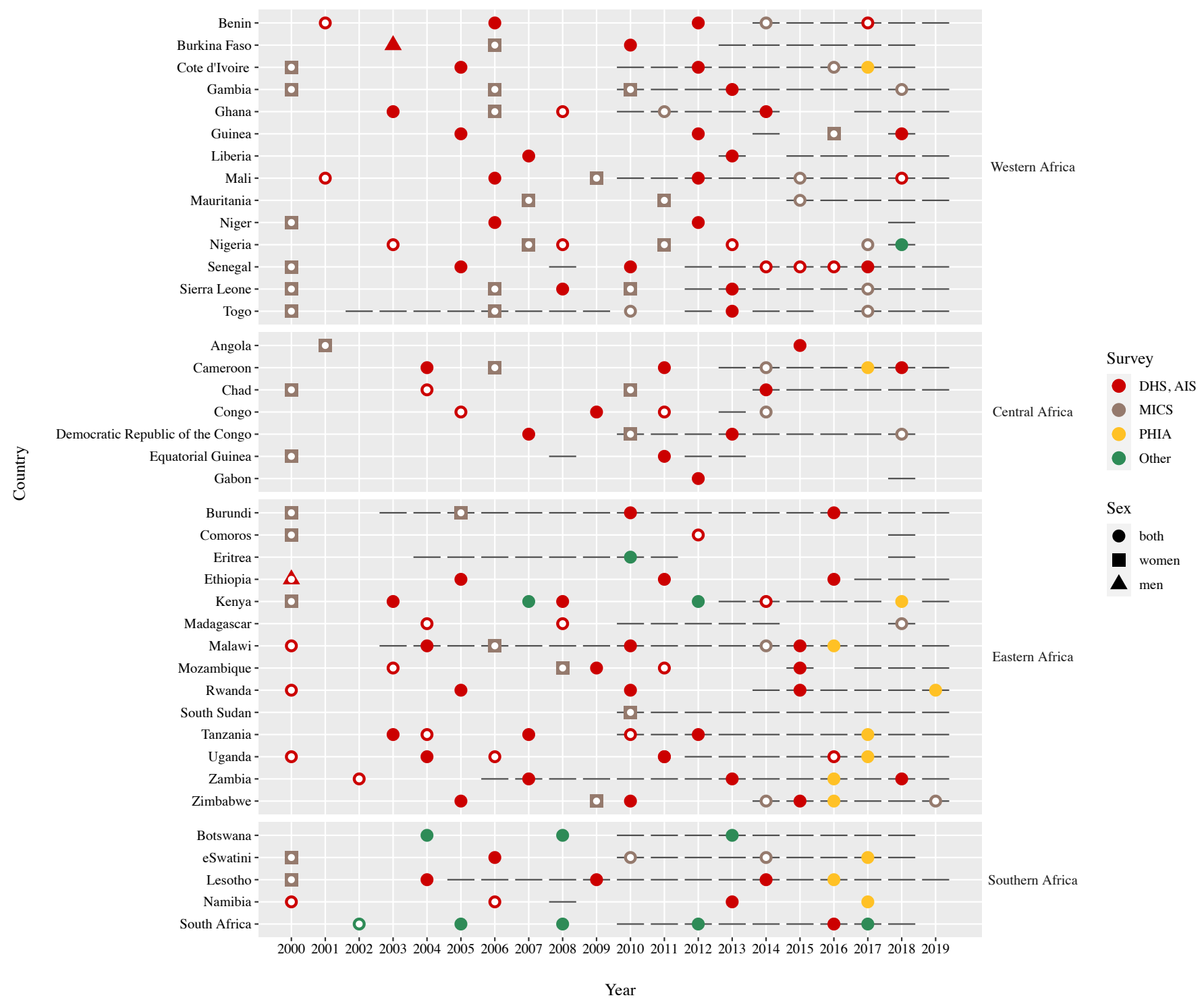

Figure 1: Summary of included surveys and HIV testing services program data by country and year, 2000-2019

Circles represent surveys that were conducted among both men and women, while squares and triangles represent surveys that were conducted among women or among men only, respectively. White dots indicate surveys where results on the proportion of individuals who self-report having ever been tested for HIV are not available by HIV status. Horizontal lines represent HIV testing services program data. DHS: Demographic Health Survey. AIS: AIDS Indicator Survey; MICS: Multiple Indicator Cluster Survey; PHIA: Population-based HIV Impact Assessment Survey. Other types of surveys include: Population Health Survey from Eritrea, South African National HIV Prevalence, Incidence, Behaviour and Communication Surveys, and Botswanan, Kenyan and Nigerian AIDS Indicator Surveys. 
A

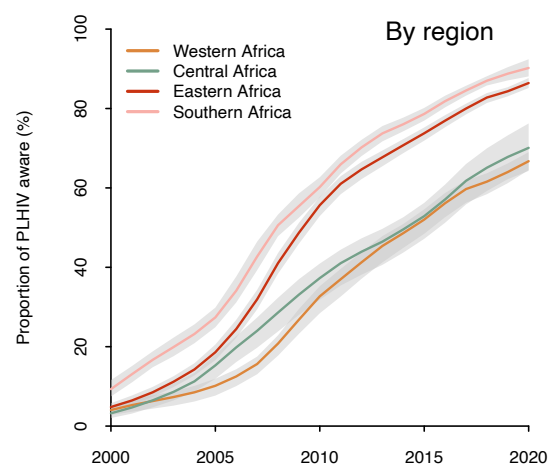

B

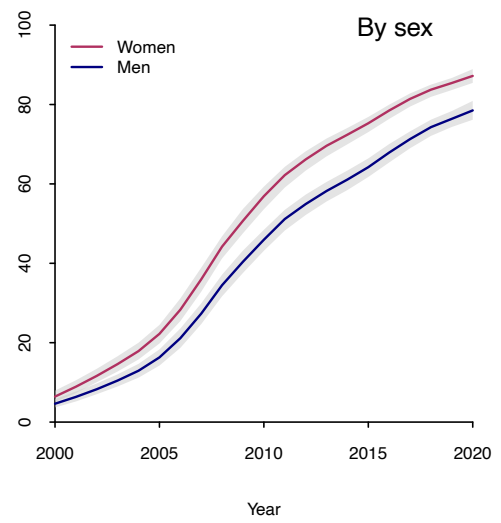

C

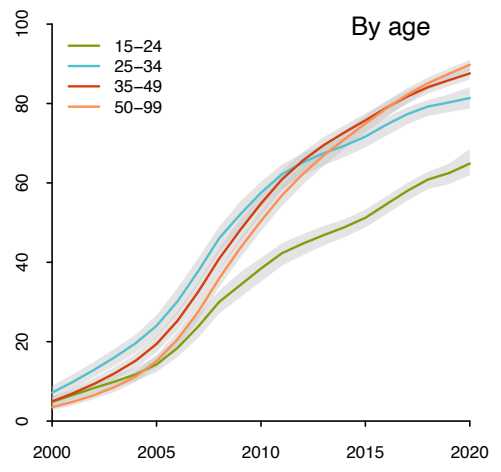

Figure 2: Progress and disparities in knowledge of HIV status in sub-Saharan Africa, 2000-2020

Panels A to C show trends in proportion of people living with HIV (PLHIV) who are aware of their HIV status in sub-Saharan Africa by region (A), by sex (B), or by age group (C). The shaded areas correspond to the $95 \%$ credible intervals. 
medRxiv preprint doi: https://doi.org/10.1101/2020.10.20.20216283; this version posted October 23, 2020. The copyright holder for this preprint (which was not certified by peer review) is the author/funder, who has granted medRxiv a license to display the preprint in perpetuity.

It is made available under a CC-BY 4.0 International license.

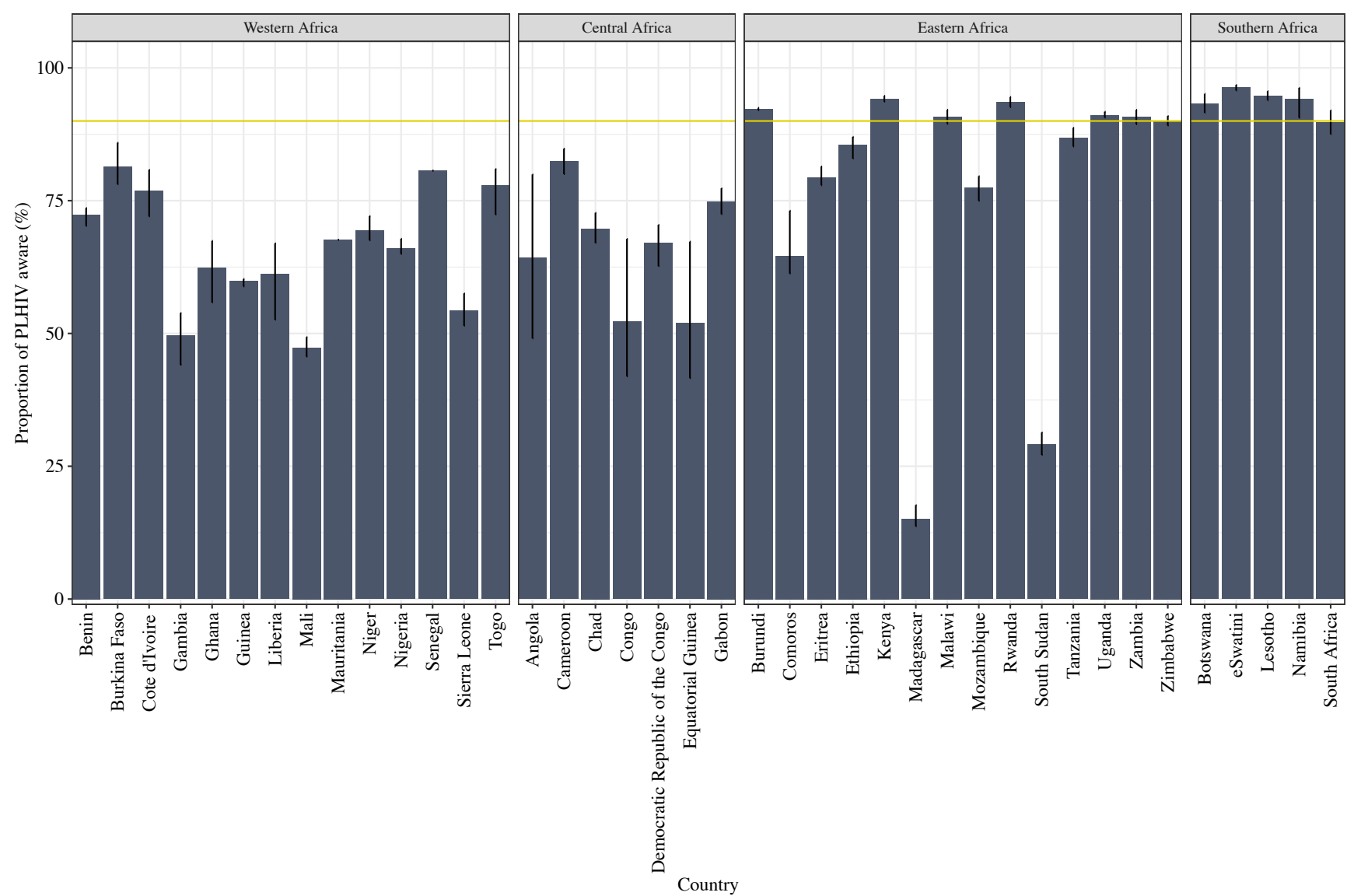

Figure 3: National estimates of knowledge of HIV status in sub-Saharan Africa, 2020

Proportion of PLHIV who know their HIV status. The horizontal yellow line represents a threshold of $90 \%$ and vertical lines correspond to the $95 \%$ credible intervals. 
medRxiv preprint doi: https://doi.org/10.1101/2020.10.20.20216283; this version posted October 23, 2020. The copyright holder for this preprint (which was not certified by peer review) is the author/funder, who has granted medRxiv a license to display the preprint in perpetuity.

\section{It is made available under a CC-BY 4.0 International license .}

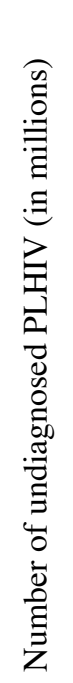
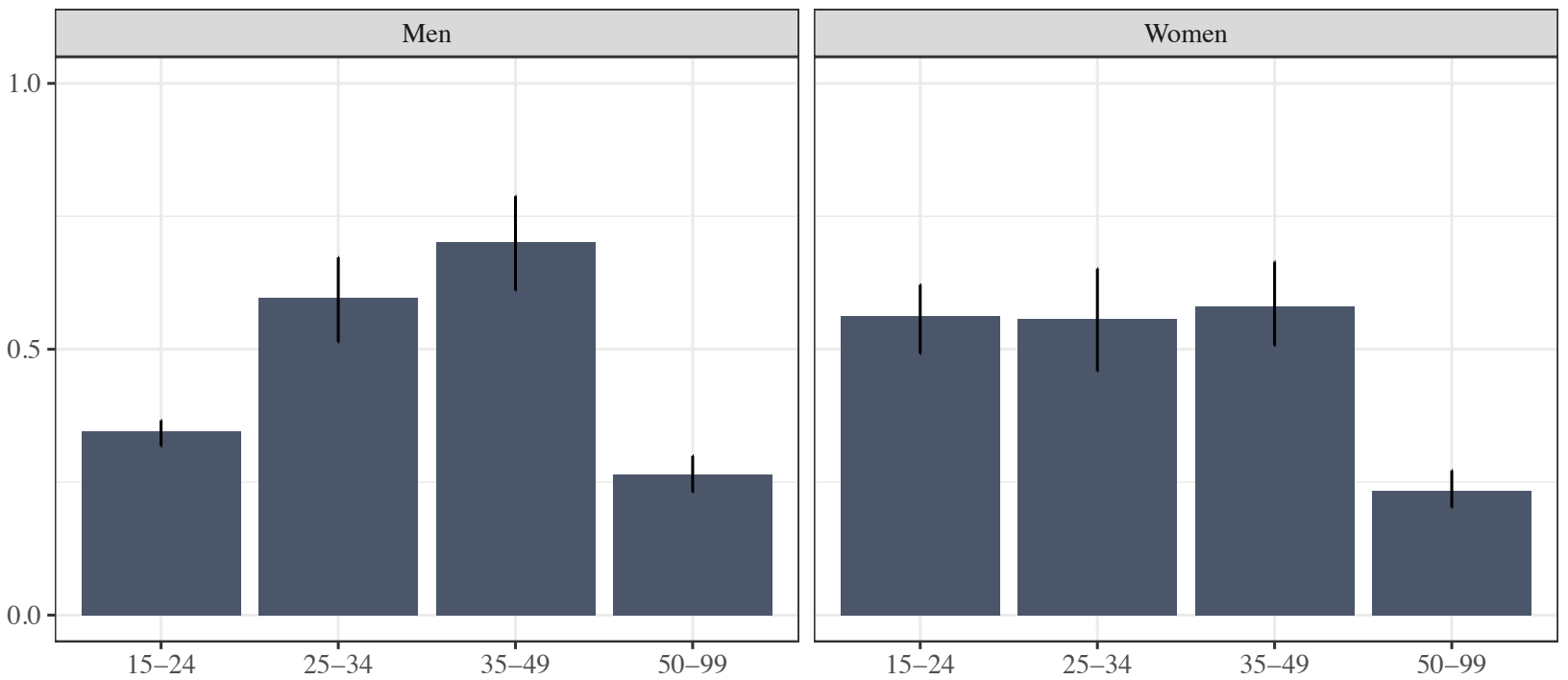

Age (years)

Figure 4: Absolute diagnosis gaps in sub-Saharan Africa, 2020

Each bar shows the total number of undiagnosed people living with HIV (PLHIV) by sex- and age-stratification. Vertical lines correspond to the $95 \%$ credible intervals. 

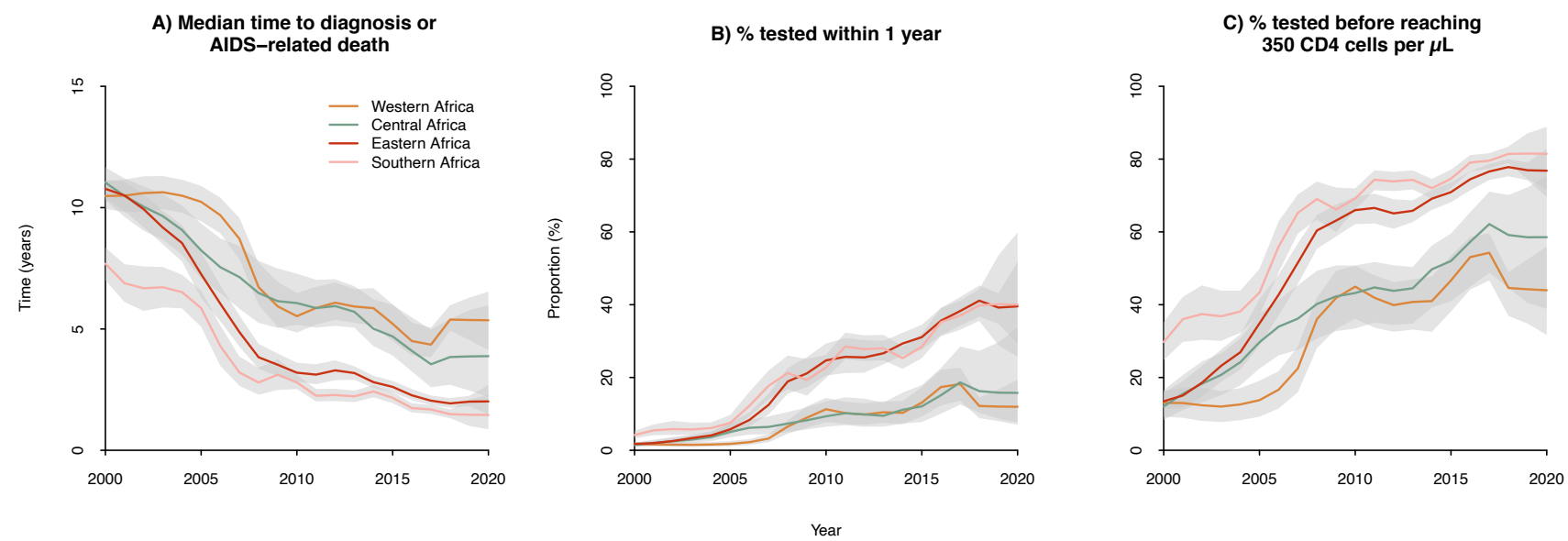

Figure 5: Progress in timeliness of HIV diagnosis in sub-Saharan Africa, 2000-2020

Regional trends in median time to diagnosis or AIDS-related death (A), in the probability to get tested within one year (B) or before reaching a CD4 count threshold lower than 350 cells per $\mu \mathrm{L}(\mathrm{C})$ were assessed through period life-table analyses. The shaded areas correspond to the $95 \%$ credible intervals. 
medRxiv preprint doi: https://doi.org/10.1101/2020.10.20.20216283; this version posted October 23, 2020. The copyright holder for this preprint (which was not certified by peer review) is the author/funder, who has granted medRxiv a license to display the preprint in perpetuity.

It is made available under a CC-BY 4.0 International license .

Table 1: Regional progress in HIV testing related outcomes among adults 15 years and older in sub-Saharan Africa, 2000-2020

\begin{tabular}{|c|c|c|c|c|c|c|c|c|c|c|c|}
\hline \multirow{6}{*}{\begin{tabular}{l}
\multicolumn{1}{c}{ Outcome } \\
Proportion of \\
individuals ( $\geq 15$ years \\
old) ever tested for \\
HIV among overall \\
population $(\%)$
\end{tabular}} & \multirow{2}{*}{$\begin{array}{l}\text { Year } \\
2000\end{array}$} & \multicolumn{2}{|c|}{ Sub-Saharan Africa } & \multicolumn{2}{|c|}{ Western Africa } & \multicolumn{2}{|c|}{ Central Africa } & \multicolumn{2}{|c|}{ Eastern Africa } & \multicolumn{2}{|c|}{ Southern Africa } \\
\hline & & $3 \cdot 6$ & $(3 \cdot 0$ to $4 \cdot 4)$ & $3 \cdot 1$ & $(2 \cdot 6$ to $3 \cdot 8)$ & 1.9 & $(1 \cdot 3$ to $2 \cdot 6)$ & $3 \cdot 3$ & $(2 \cdot 8$ to $3 \cdot 9)$ & 10 & $(8 \cdot 3$ to 13$)$ \\
\hline & 2005 & 11 & (10 to 12$)$ & $7 \cdot 2$ & $(6 \cdot 6$ to $7 \cdot 8)$ & $7 \cdot 8$ & $(6 \cdot 6$ to $9 \cdot 2)$ & 13 & (12 to 14$)$ & 30 & (29 to 32$)$ \\
\hline & 2010 & 30 & (29 to 32 ) & 19 & (18 to 19$)$ & 19 & (17 to 22$)$ & 41 & (39 to 42 ) & 59 & (58 to 61 ) \\
\hline & 2015 & 41 & (40 to 42 ) & 28 & (27 to 29 ) & 29 & (28 to 30 ) & 53 & (52 to 54 ) & 75 & (74 to 75 ) \\
\hline & 2020 & 51 & (49 to 54$)$ & 36 & (34 to 39$)$ & 42 & (39 to 48$)$ & 64 & (62 to 66$)$ & 85 & (83 to 88$)$ \\
\hline \multirow{5}{*}{$\begin{array}{l}\text { Proportion of PLHIV } \\
\text { who know their HIV } \\
\text { status }(\%)\end{array}$} & 2000 & $5 \cdot 7$ & $(4 \cdot 6$ to $7 \cdot 0)$ & $4 \cdot 0$ & $(2 \cdot 8$ to $5 \cdot 2)$ & $3 \cdot 2$ & $(2 \cdot 0$ to $4 \cdot 6)$ & $4 \cdot 8$ & $(4 \cdot 0$ to $5 \cdot 8)$ & $9 \cdot 3$ & $(7 \cdot 5$ to 12$)$ \\
\hline & 2005 & 20 & (18 to 22$)$ & 10 & $(7 \cdot 7$ to 12$)$ & 15 & (12 to 18$)$ & 19 & (17 to 21 ) & 27 & (25 to 30$)$ \\
\hline & 2010 & 53 & (50 to 55$)$ & 33 & (28 to 35$)$ & 37 & (32 to 41$)$ & 56 & (53 to 58 ) & 60 & (58 to 63 ) \\
\hline & 2015 & 71 & (69 to 73 ) & 52 & (48 to 55$)$ & 53 & (47 to 56 ) & 74 & (72 to 75 ) & 79 & (77 to 80 ) \\
\hline & 2020 & 84 & $(82$ to 86$)$ & 67 & (65 to 69$)$ & 70 & (64 to 76$)$ & 86 & (85 to 88$)$ & 90 & (88 to 92$)$ \\
\hline \multirow{5}{*}{$\begin{array}{l}\text { Time to diagnosis or } \\
\text { AIDS-related death, } \\
\text { median (year) }\end{array}$} & 2000 & $9 \cdot 6$ & $(9 \cdot 1$ to 10$)$ & 11 & (10 to 11$)$ & 11 & (10 to 12$)$ & 11 & (10 to 11 ) & $7 \cdot 7$ & $(7 \cdot 0$ to $8 \cdot 4)$ \\
\hline & 2005 & $7 \cdot 2$ & $(6 \cdot 3$ to $8 \cdot 0)$ & 10 & $(9 \cdot 4$ to 11$)$ & $8 \cdot 2$ & $(7 \cdot 1$ to $9 \cdot 3)$ & $7 \cdot 3$ & $(6 \cdot 3$ to $8 \cdot 2)$ & $5 \cdot 9$ & $(5 \cdot 1$ to $6 \cdot 6)$ \\
\hline & 2010 & $3 \cdot 6$ & $(3 \cdot 2$ to $4 \cdot 1)$ & $5 \cdot 5$ & $(4 \cdot 9$ to $6 \cdot 5)$ & $6 \cdot 1$ & $(5 \cdot 2$ to $7 \cdot 3)$ & $3 \cdot 2$ & $(2 \cdot 8$ to $3 \cdot 6)$ & $2 \cdot 8$ & $(2 \cdot 5$ to $3 \cdot 1)$ \\
\hline & 2015 & $3 \cdot 0$ & $(2 \cdot 7$ to $3 \cdot 4)$ & $5 \cdot 2$ & $(4 \cdot 5$ to $6 \cdot 0)$ & $4 \cdot 7$ & $(3 \cdot 9$ to $6 \cdot 0)$ & $2 \cdot 6$ & (2.4 to $2 \cdot 9)$ & $2 \cdot 2$ & (1.9 to $2 \cdot 4)$ \\
\hline & 2020 & $2 \cdot 6$ & $(1 \cdot 8$ to $3 \cdot 5)$ & $5 \cdot 4$ & $(4 \cdot 1$ to $6 \cdot 5)$ & $3 \cdot 9$ & $(2 \cdot 2$ to $6 \cdot 0)$ & $2 \cdot 0$ & ( 1.5 to $2 \cdot 7)$ & $1 \cdot 5$ & $(0.9$ to 2.3$)$ \\
\hline \multirow{5}{*}{$\begin{array}{l}\text { Probability of getting } \\
\text { tested within } 1 \text { year } \\
\text { following infection } \\
(\%)\end{array}$} & 2000 & $2 \cdot 6$ & $(2 \cdot 1$ to $3 \cdot 3)$ & $1 \cdot 6$ & $(1 \cdot 1$ to $2 \cdot 1)$ & $1 \cdot 5$ & $(1 \cdot 0$ to $2 \cdot 1)$ & $1 \cdot 7$ & $(1 \cdot 4$ to $2 \cdot 1)$ & $4 \cdot 2$ & $(3 \cdot 3$ to $5 \cdot 3)$ \\
\hline & 2005 & $5 \cdot 9$ & $(4 \cdot 5$ to $7 \cdot 7)$ & $1 \cdot 8$ & $(1 \cdot 1$ to $2 \cdot 6)$ & $5 \cdot 1$ & $(3 \cdot 6$ to $7 \cdot 1)$ & $5 \cdot 8$ & $(4 \cdot 4$ to $7 \cdot 6)$ & $7 \cdot 5$ & ( $5 \cdot 8$ to $9 \cdot 7)$ \\
\hline & 2010 & 21 & (18 to 25$)$ & 11 & $(7 \cdot 7$ to 14$)$ & $9 \cdot 3$ & $(6 \cdot 5$ to 13$)$ & 25 & (21 to 29$)$ & 23 & (20 to 26$)$ \\
\hline & 2015 & 26 & (23 to 30 ) & 13 & $(9 \cdot 3$ to 17$)$ & 12 & $(7 \cdot 8$ to 18$)$ & 31 & (28 to 35 ) & 28 & (25 to 32 ) \\
\hline & 2020 & 33 & (23 to 46$)$ & 12 & $(7 \cdot 0$ to 19$)$ & 16 & ( $7 \cdot 6$ to 34$)$ & 40 & (29 to 52$)$ & 40 & (26 to 60$)$ \\
\hline \multirow{5}{*}{$\begin{array}{l}\text { Probability of getting } \\
\text { tested before reaching } \\
\text { a CD4 count lower } \\
\text { than } 350 \text { cells/ } \mu \mathrm{L}(\%)\end{array}$} & 2000 & 19 & (16 to 23$)$ & 13 & $(9 \cdot 3$ to 16$)$ & 12 & $(8 \cdot 3$ to 17$)$ & 14 & (11 to 16$)$ & 30 & (25 to 35$)$ \\
\hline & 2005 & 35 & (29 to 42 ) & 14 & $(9 \cdot 2$ to 19$)$ & 30 & (22 to 38$)$ & 35 & (29 to 42 ) & 43 & (37 to 50$)$ \\
\hline & 2010 & 63 & (58 to 66$)$ & 45 & (36 to 51$)$ & 43 & (34 to 51 ) & 66 & (62 to 70$)$ & 69 & (66 to 72 ) \\
\hline & 2015 & 67 & (63 to 70$)$ & 47 & (38 to 53 ) & 52 & (41 to 60 ) & 71 & (68 to 74$)$ & 75 & (72 to 77 ) \\
\hline & 2020 & 71 & (62 to 79$)$ & 44 & (32 to 56$)$ & 59 & (39 to 75$)$ & 77 & (70 to 83 ) & 81 & (72 to 89$)$ \\
\hline \multirow{5}{*}{$\begin{array}{l}\text { Positivity ( } \% \text { of } \\
\text { positive tests among } \\
\text { all tests) }\end{array}$} & 2000 & $9 \cdot 0$ & $(7 \cdot 7$ to 10$)$ & $3 \cdot 0$ & $(2 \cdot 1$ to $3 \cdot 5)$ & $4 \cdot 6$ & $(3 \cdot 5$ to $5 \cdot 2)$ & 11 & (9.6 to 12$)$ & 15 & (13 to 19$)$ \\
\hline & 2005 & 11 & $(9 \cdot 2$ to 14$)$ & $4 \cdot 0$ & $(3 \cdot 3$ to $4 \cdot 5)$ & $5 \cdot 4$ & $(4 \cdot 2$ to $6 \cdot 7)$ & 10 & $(9 \cdot 1$ to 12$)$ & 20 & (16 to 26$)$ \\
\hline & 2010 & $5 \cdot 9$ & $(4 \cdot 3$ to $8 \cdot 3)$ & $2 \cdot 6$ & $(2 \cdot 0$ to $3 \cdot 2)$ & $5 \cdot 0$ & $(3 \cdot 6$ to $6 \cdot 9)$ & $5 \cdot 6$ & $(4 \cdot 2$ to $7 \cdot 5)$ & 13 & $(9 \cdot 0$ to 22$)$ \\
\hline & 2015 & $4 \cdot 3$ & $(3 \cdot 5$ to $5 \cdot 2)$ & $2 \cdot 2$ & $(1 \cdot 7$ to $2 \cdot 7)$ & $3 \cdot 4$ & $(2 \cdot 4$ to $4 \cdot 7)$ & $4 \cdot 0$ & $(3 \cdot 5$ to $4 \cdot 6)$ & $9 \cdot 2$ & $(7 \cdot 1$ to 13$)$ \\
\hline & 2020 & $2 \cdot 8$ & $(2 \cdot 1$ to $3 \cdot 9)$ & $1 \cdot 9$ & $(1 \cdot 3$ to $2 \cdot 7)$ & $2 \cdot 2$ & $(1 \cdot 4$ to $3 \cdot 3)$ & $2 \cdot 5$ & ( 1.9 to 3.3$)$ & $5 \cdot 5$ & ( 3.8 to $8 \cdot 4)$ \\
\hline \multirow{5}{*}{$\begin{array}{l}\text { Diagnosis yield (\% of } \\
\text { new diagnoses among } \\
\text { all tests) }\end{array}$} & 2000 & $7 \cdot 9$ & $(7 \cdot 0$ to $8 \cdot 6)$ & $2 \cdot 6$ & $(1 \cdot 8$ to $2 \cdot 9)$ & $4 \cdot 2$ & $(3 \cdot 2$ to $4 \cdot 7)$ & $9 \cdot 7$ & $(8 \cdot 8$ to 11$)$ & 13 & (12 to 14$)$ \\
\hline & 2005 & $7 \cdot 8$ & $(7 \cdot 0$ to $8 \cdot 4)$ & $3 \cdot 2$ & $(2 \cdot 7$ to $3 \cdot 6)$ & $3 \cdot 8$ & $(3 \cdot 1$ to $4 \cdot 3)$ & $7 \cdot 6$ & $(7 \cdot 0$ to $8 \cdot 1)$ & 14 & (12 to 15$)$ \\
\hline & 2010 & $2 \cdot 8$ & $(2 \cdot 4$ to $3 \cdot 3)$ & $1 \cdot 5$ & $(1 \cdot 2$ to $1 \cdot 7)$ & $2 \cdot 6$ & $(2 \cdot 1$ to $3 \cdot 0)$ & $2 \cdot 4$ & $(2 \cdot 1$ to $2 \cdot 9)$ & $6 \cdot 9$ & $(6 \cdot 2$ to $7 \cdot 5)$ \\
\hline & 2015 & 1.9 & $(1 \cdot 7$ to $2 \cdot 1)$ & $1 \cdot 1$ & $(0 \cdot 9$ to $1 \cdot 3)$ & $1 \cdot 6$ & $(1 \cdot 2$ to $1 \cdot 8)$ & $1 \cdot 7$ & $(1.6$ to 1.8$)$ & $4 \cdot 4$ & $(4 \cdot 1$ to $4 \cdot 6)$ \\
\hline & 2020 & $1 \cdot 2$ & $(0.9$ to $1 \cdot 5)$ & $1 \cdot 0$ & $(0 \cdot 7$ to $1 \cdot 5)$ & 0.9 & $(0.6$ to $1 \cdot 3)$ & $1 \cdot 0$ & $(0.8$ to 1.3$)$ & $2 \cdot 2$ & (1.6 to 2.9$)$ \\
\hline \multirow{5}{*}{$\begin{array}{l}\text { Proportion of new } \\
\text { HIV diagnoses among } \\
\text { all positive tests }(\%)\end{array}$} & 2000 & 89 & (77 to 96 ) & 86 & (79 to 94 ) & 93 & (85 to 97$)$ & 91 & (85 to 95$)$ & 87 & (70 to 97$)$ \\
\hline & 2005 & 72 & (55 to 86$)$ & 79 & (71 to 90$)$ & 71 & (55 to 86$)$ & 74 & (61 to 84$)$ & 70 & (48 to 87 ) \\
\hline & 2010 & 48 & (33 to 65 ) & 56 & (46 to 73 ) & 52 & (36 to 71 ) & 44 & (32 to 59 ) & 53 & (31 to 76$)$ \\
\hline & 2015 & 44 & (37 to 53 ) & 48 & (38 to 61$)$ & 46 & (33 to 59 ) & 42 & (37 to 48 ) & 47 & (34 to 60$)$ \\
\hline & 2020 & 42 & (30 to 55$)$ & 52 & (38 to 68$)$ & 42 & (24 to 57$)$ & 41 & (30 to 52$)$ & 39 & (25 to 55$)$ \\
\hline
\end{tabular}

PLHIV: people living with HIV, HTS: HIV testing services· Numbers in parentheses correspond to $95 \%$ credible intervals 